\title{
Stress akademik akibat Covid-19
}

\author{
Mufadhal Barseli ${ }^{1}$, Ifdil Ifdil ${ }^{\left.2^{*}\right)}$, Linda Fitria ${ }^{3}$ \\ ${ }^{13}$ Universitas Putra Indonesia YPTK Padang \\ ${ }^{2}$ Universitas Negeri Padang
}

\begin{tabular}{lll} 
Article Info & ABSTRACT \\
\cline { 3 - 4 } Article history: & & $\begin{array}{l}\text { Selama proses pembelajaran daring yang diberlakukan selama pandemic } \\
\text { Covid-19 banyak menimbulkan stress akademik terutama pada siswa. Hal ini }\end{array}$ \\
Received Jul $31^{\text {st }}, 2020$ & & menunjukkan perlu adanya upaya guru Bimbingan dan Konseling atau \\
Revised Aug $27^{\text {th }}, 2020$ & konselor untuk melakukan pengembangan pada praktik pelayanan \\
Accepted Sep $29^{\text {th }}, 2020$ & Binbingan dan konseling untuk meningkatkan kualitas atau potensi siswa \\
& dalam mengantisipasi muculnya stres akademik siswa selama covid-19 \\
Keyword: & dan faktor-faktor yang mempengaruhi munculnya stres akademik. Naskah \\
Stress akademik & ini akan mengenalkan gambaran stres akademik siswa selama covid-19 \\
COVID-19 & meliputi; konsep stres, konsep stres akademik, dan memngelola stres \\
selama pandemic Covid-19 Semoga ini dapat digunakan sebagai salah satu & rujukan.
\end{tabular}

C 2020 The Authors. Published by IICET.

cC)(1) This is an open access article under the CC BY-NC-SA license

BY NC SA (https://creativecommons.org/licenses/by-nc-sa/4.0

\section{Corresponding Author:}

Ifdil Ifdil,

Universitas Negeri Padang

Email: ifdil@konselor.org

\section{Pendahuluan}

Pada bulan Maret 2020 lebih dari 800 juta siswa di dunia melakukan pembelajaran di rumah sebagai akibat dari pandemi covid-19 (Arika, 2020). Kebijakan belajar di rumah ini dilakukan untuk mengurangi interaksi fisik sebagai upaya pencegahan penularan virus corona jenis baru atau covid-19. Mendikbud berharap dengan diterapkannya pembelajaran daring atau jarak jauh ini siswa juga mendapatkan pengalaman baru dalam proses belajar (Fajar, 2020).

Pembelajaran yang dilakukan secara daring memiliki beberapa kelebihan dalam penerapannya Pembelajaran daring membuat kegiatan belajar mengajar menjadi dapat dijangkau dari berbagai waktu dan tempat (Shukla, Dosaya, Nirban, \& Vavilala, 2020). Penggunaan media daring juga memungkinkan siswa untuk mendapatkan informasi yang lebih luas melalui internet (Hastini, Fahmi, \& Lukito, 2020). Pemanfaatan teknologi ini dianggap sangat membantu dalam melangsungkan pembelajaran selama pembatasan sosial di masa pandemi Covid-19 (Pakpahan \& Fitriani, 2020).

Berbagai kendala juga muncul dalam penerapan pembelajaran daring. Pembelajaran melalui internet menjadi hal yang sulit dilakukan di beberapa daerah tertentu dengan jaringan yang tidak memadai (Hastini et al., 2020). Kendala-kendala yang juga dihadapi oleh siswa seperti paket internet yang habis, pekerjaan rumah yang harus dikerjakan juga, dan tugas sekolah yang menumpuk. Berbagai tuntutan akademik yang harus diselesaikan oleh siswa menyebabkan mereka mengalami stres akademik. Ketidakmampuan mahasiswa untuk beradaptasi dengan keadaan tersebut membuat mereka mengalami stres. 
Alvin (dalam Eryanti, 2012) stres akademik adalah tekanan-tekanan yang terjadi di dalam diri siswa yang disebabkan oleh persaingan maupun tuntutan akademik. Senada dengan hal tersebut (Taufik, T., \& Ifdil, I. 2013; Muharrifah, A. 2009) menjelaskan stres akademik muncul ketika harapan untuk meraih prestasi akademik meningkat, baik dari orang tua, guru maupun teman sebaya. Harapan tersebut sering tidak sesuai dengan kemampuan yang dimiliki siswa sehingga menimbulkan tekanan psikologis yang mempengaruhi pencapaian prestasi belajar di sekolah.

Stres akademik disebabkan oleh adanya academic stressor (Sayekti dalam Barseli, 2017). Academic stressor merupakan yaitu penyebab stres yang bermula dari proses pembelajaran seperti tekanan untuk mendapatkan nilai yang baik, lamanya belajar, banyaknya tugas, rendahnya nilai/prestasi dan cemas dalam menghadapi ujian (Rahmawati dalam Barseli, dkk, 2017).

Penerapan kebijakan belajar di rumah membuat sebagian siswa merasa cemas dan tertekan. Banyaknya tugas yang diberikan oleh guru membuat banyak siswa merasa stres dalam menjalani pembelajaran daring (Chaterine, 2020). Tidak hanya banyak, tugas yang diberikan oleh guru juga dianggap memberatkan dan memiliki waktu pengerjaan yang sangat singkat sehingga membuat siswa kebingungan dalam menyelesaikan tugas-tugasnya (Raharjo \& Sari, 2020).

Dengan banyaknya tugas yang diberikan siswa bisa menghabiskan waktu dari pagi hingga malam hari hanya untuk menyelesaikan berbagai tugas daringnya. Kondisi tersebut sebelumnya tidak terjadi ketika kegiatan belajar mengajar masih dilakukan di sekolah.

\section{Pembahasan}

\section{Stress}

Stres merupakan suatu kondisi yang disebabkan adanya ketidaksesuaian (Garniwa, I. 2007) antara situasi yang diinginkan dengan keadaan biologis, psikologis atau sistem sosial individu (Sarafino, 2006; Wardi, R., \& Ifdil, I. (2016). (Anggola \& Ongori 2009; Pratama, M. R., 2015; Siska, M., 2011) juga mendefinisikan stres sebagai persepsi dari kesenjangan antara tuntutan lingkungan dan kemampuan individu untuk memenuhinya.

Stres merupakan respon individu terhadap keadaan atau kejadian yang memicu stres (stresor), yang mengancam dan mengganggu kemampuan seseorang untuk menanganinya (coping) (Santrock, 2007; Diponegoro, A. M., \& Thalib, S. B. 2001; Dari, P. T. S. D., \& Ibu, D. S. 2012).

Robbins (2001) menyatakan bahwa stres merupakan suatu kondisi yang menekan keadaan psikis seseorang dalam mencapai sesuatu kesempatan di mana untuk mencapai kesempatan tersebut terdapat batasan atau penghalang. Weinberg dan Gould (2003) mendefinisikan stres sebagai "a substantial imbalance between demand (physical and psychological) and response capability, under condition where failure to meet that demand has importance concequences". Artinya, ada ketidakseimbangan antara tuntutan (fisik dan psikis) dan kemampuan memenuhinya. Gagal dalam memenuhi kebutuhan tersebut akan berdampak krusial.

Hampir senada dengan pendapat di atas, Sarafino (1994) mendefinisikan stress sebagai tekanan internal maupun eksternal serta kondisi bermasalah lainnya dalam kehidupan (an internal and external pressure and other troublesome condisition in life). Beberapa konsep tersebut menjelaskan stress sebagai sebuah kondisi yang disebabkan oleh interaksi antara individu dengan lingkungan, menimbulkan persepsi jarak antara tuntutan-tuntutan yang berasal dari situasi yang bersumber pada sistem biologis, psikologis, dan sosial dari seseorang.

Dari paparan di atas dapat dipahami bahwa Stress adalah respons organisme untuk menyesuaikan diri dengan tuntutan-tuntutan yang berlangsung. Tuntutan tersebut dapat berupa hal-hal yang faktual terjadi, atau hal-hal baru yang mungkin akan terjadi, tetapi dipersepsi secara aktual. Apabila kondisi tersebut tidak teratasi dengan baik maka terjadilah gangguan pada satu atau lebih organ tubuh yang mengakibatkan yang bersangkutan tidak dapat menjalankan fungsi pekerjaannya dengan baik.

Dengan redaksi yang lebih sederhana, stress adalah suatu keadaan tidak mengenakkan atau tidak nyaman yang dialami oleh individu dan keadaan tersebut mengganggu pikiran, emosional, tindakan atau perilaku dalam kehidupan sehari-hari. Kondisi tersebut bersifat individual dan subjektif.

\section{Stress akademik}

Stres yang terjadi di lingkungan sekolah atau pendidikan biasanya disebut dengan stres akademik (Sinaga, M. A. J. 2015; Rahmadani, C. S. M. 2014; Hikmah, Y. 2014; ). Desmita (2010) menyatakan "Stres akademik adalah stres yang disebabkan oleh academic stresor". Academic stresor adalah stres yang dialami siswa yang bersumber dari proses pembelajaran atau hal-hal yang berhubungan dengan kegiatan belajar 
seperti: tekanan untuk naik kelas, lama belajar, mencontek, banyak tugas, mendapat nilai ulangan, keputusan menentukan jurusan atau karier serta kecemasan ujian dan manajemen stres.

Stress akademik adalah respons yang muncul karena terlalu banyaknya tuntutan dan tugas yang harus dikerjakan siswa/mahasiswa. Kondisi stress disebabkan adanya tekanan untuk menunjukkan prestasi dan keunggulan dalam kondisi persaingan akademik yang semakin meningkat sehingga mereka semakin terbebani oleh berbagai tekanan dan tuntutan. Stress akademik yang dialami siswa merupakan hasil persepsi yang subyektif terhadap adanya ketidaksesuaian antara tuntutan lingkungan dengan sumber daya aktual yang dimiliki siswa.

Masalah yang dihadapi siswa/mahasiswa ada masa pandemi Covid-19 ini selain tuntutan-tuntutan yang dibebankan dengan model belajar mengajar secara daring. Proses belajar menggunakan media online lebih melelahkan dan membosankan, karena mereka tidak dapat berinteraksi langsung baik dengan guru maupun teman lainnya. Dengan demikian mengakibatkan frustrasi bagi siswa/mahasiswa, dan bila terus berlanjut dapat menimbulkan stress.

\section{Mengelola stress di masa pandemi Covid-19 \\ Mengenali Penyebab Stress di Masa Pandemic Covid-19}

Di saat pandemi ini yang menjadi sumber stress (stressor) adalah berita mengenai Covid-19 dan pembatasan sosial yang dilakukan oleh pemerintah. Oleh sebab itu masyarakat dituntut untuk bijak dalam membaca berita. Harus dari sumber yang valid karena sering kali berita hoax yang ada. Informasi yang ada harus dipilih dan dipilah. Mencari informasi dari sumber yang terpercaya, adalah salah satu solusi, tidak gampang percaya berita-berita yang mengakibatkan semakin cemas, khawatir dan gelisah. Karena mempercayai berita yang membuat kecemasan, kekhawatiran dan kegelisahan menjadi salah satu pemicu stress.

Dalam mengelola stress perlu diketahui faktor penyebab stress. Daradjat (2003) disebutkan ada 3 hal yang menyebabkan kondisi tidak stress seseorang, yaitu: 1) Frustasi, hampir seluruh proses belajar mengajar dilakukan secara daring (online). Bagi siswa/mahasiswa yang mempunyai fasilitas untuk dapat mengakses PBM secara online tidak ada masalah. Akan tetapi faktanya tidak seluruh wilayah di bumi Nusantara ini dapat mengakses fasilitas berbasis IT tersebut. Anak akan stress, karena apa yang terjadi tidak sesuai dengan haarapan. Tidak ada alat komunikasi (HP) dan paket data atau jaringan internet yang bagus dapat menjadi penyebab tidak lancarnya proses belajar mengajar, sehingga harapan siswa/mahasiswa tidak sesuai dengan kenyataan; 2) Konflik, adanya pertentangan antara dua kepentingan atau lebih dapat membuat orang mengalami kecemasan. Sebagai contoh bagi pekerja, apakah dia harus WFH atau WFO, keduanya bisa memunculkan konflik; 3) Kecemasan, perpaduan antara konflik dan frustrasi dapat mengakibatkan kecemasan. Kondisi inilah yang ditemukan pada beberapa kasus pemicu stress. Sebagai contoh adanya deadline tugas yang harus diselesaikan membuat siswa/mahasiswa merasa tertekan dalam menghadapi kesehariannya yang akan berakibat timbulnya stress.

\section{Mengatasi stress}

Stress dapat mempengaruhi kondisi fisik, mental dan emosi seseorang. Maka dari itu penting bagi setiap orang untuk memiliki pengetahuan dan kemampuan dalam mengatasu stress. PMI menyebutkan 5 teknik manajemen stress dalam buku Panduan Manajemen Stres: 1) Mengenal diri sendiri. Mengetahui kekuatan, kelemahan, hal-hal yang disukai dan yang tidak disukai dapat membantu kita memetakan ke arah mana kehidupan akan kita bawa. Dengan mengenal diri sendiri, akan lebih mudah untuk menentukan cara dan strategi apa yang tepat untuk meringankan stress; 2) Peduli diri sendiri. Setelah mengetahui diri secara mendalam, maka kebutuhan- kebutuhan dan kewajiban juga akan tampak. Memenuhi kebutuhan diri sendiri merupakan salah satu cara untuk mengatur stres yang dihadapi. Peduli akan diri sendiri dapat dimulai dengan mencoba pola hidup sehat, bersosialisasi dengan teman dan sanak saudara, merencanakan kegiatan yang realistis dan menjalani hobi; 3) Perhatikan keseimbangan. Sebagaimana manusia yang dianugerahi beberapa aspek dalam dirinya, maka kelima aspek ini harus dipelihara dan dipenuhi secara seimbang. Lima aspek pemeliharaan diri ini adalah: Aspek Mental Emosional, Aspek Intelektual, Aspek Fisik, Aspek Spiritual dan Aspek Rekreasional; 4) Bersikap proaktif dalam mencegah gangguan stres dengan merawat kelima aspek di atas dengan baik dan rutin agar menjadi sosok yang resilien dan memiliki kemampuan dan kekuatan lebih dalam menghadapi stres; 5) Sinergi: Langkah-langkah sebelumnya ialah satuan proses yang perlu dilakukan secara berurutan dan terpadu dengan kehendak dan kesadaran penuh untuk bangkit dari keterpurukan dan stres. (Palang Merah Indonesia: 2015)

Masyarakat Indonesia yang religius memandang Covid-19 sebagai ujian yang harus dilalui. Berpikir positif dengan selalu menjaga imunitas tubuh dan spiritualitas menjadi salah satu cara agar terhindar dari stress. Memanfaatkan waktu yang sebaik-baiknya untuk beraktivitas secara positif dengan tetap memperhatikan protokol kesehatan menjadi solusi dalam menghadapi stress di masa pandemi Covid- 


\section{Simpulan}

Dari penjelasan di atas dapat disimpulkan bahwa beragam respons terhadap kondisi pandemi Covid-19. Untuk mencegah semakin meluasnya penyebaran virus corona tersebut, Pemerintah menetapkan kebijakan WFH (Work From Home) dan Sosial Distancing. Dampak dari pandemi Covid-19 menyebabkan orang harus menjalankan semua aktivitasnya di dalam rumah. Suasana sungguh mencekam, hiruk pikuk kehidupan manusia seakan mati, tanpa ada tanda-tanda kehidupan. Kondisi tersebut membuat sebagian orang mengalami stress. Stres akademik bukan hal baru dari permasalah siswa, namun upaya intensif untuk pengelolaan stres akademik siswa sepertinya tidak banyak dilakukan di Indonesia, kondisi ini terlihat dari tidak banyaknya penelitian tentang stres akademik. Hal ini disebabkan belum bayak riset berkenaan dengan stres akademik siswa. Diharapkan pelayanan bimbingan dan konseling mampu mengatasi permasalahan stress akademik yang dialami siswa selama pandemic Covid-19.

\section{References}

Anggola, J.E., \& Ongori, H. 2009. "An Asessment of Academic Stress Among Undergraduate Students: The case of university of botswana". Educational research and reviews, 4 (2): 063-070.

Arika, Y. (2020, March 18). Lebih dari 849 juta siswa di dunia belajar di rumah. Kompas. Retrieved from https://kompas.id/baca/humaniora/dikbud/2020/03 /18/lebih-dari-849-juta-siswa-di-dunia-belajar-dirumah.

Barseli, dkk. (2017). Konsep Stres Akademik Siswa. Jurnal Konseling dan Pendidikan, 5 (03): 143-148.

Chaterine, R. N. (2020, March 18). Siswa belajar dari rumah, KPAI: Anak-anak stres dikasih banyak tugas. Detik News.Retrievedfrom https://news.detik.com/berita/d-4944071/siswa- belajar-dari-rumah-kpaianak-anak-stres-dikasih- banyak-tugas.

Desmita. 2010. Psikologi Perkembangan Peserta Didik. Bandung: Remaja Rosdakarya.

Drajat, zakiyah.2003. Kesehatan Mental. Jakarta:Gunung Agung

Eryanti, F. (2012). Perbedaan Stres Akademik antara kelompok Siswa Minoritas dengan Mayoritas di SMP WR Supratman 2 medan. Jurnal USU, 7 (06): 145-162.

Fajar, T. (2020, March 25). Arti belajar di rumah ditengah wabah virus corona. Okezone News. Retrieved from https://news.okezone.com/read/2020/03/25/65/2188872/arti-belajar-di-rumah-ditengah-wabah.

Garniwa, I. 2007. Pengaruh stress kerja terhadap motivasi serta dampaknya terhadap prestasi kerja sdosen tetap universitas widyatama.

Hastini, L. Y., Fahmi, R., \& Lukito, H. (2020). Apakah pembelajaran menggunakan teknologi dapat meningkatkan literasi manusia pada generasi $\mathrm{Z}$ di Indonesia? Jurnal Manajemen Informatika (JAMIKA), 10(1), 12-28.

Hikmah, Y. 2014. Pengaruh Layanan Konseling Kelompok Eklektik Dalam Mengurangi Stress pada Anak

Berprestasi Belajar Tinggi Siswa Kelas Xi Sma Negeri 8 Medan Tahun Ajaran 2014/2015 (Doctoral dissertation, UNIMED).

Muharrifah, A. 2009. Interaksi antara Remaja, Ayah, dan Sekolah Serta Hubungannya dengan Tingkat Stres dalam Menghadapi Ujian Nasional (Doctoral dissertation).

Palang Merah Indonesia (PMI) Editor: Herry Prasetyo. 2015. Panduan-Manajemen Stres, Jakarta: PMI

Pakpahan, R., \& Fitriani, Y. (2020). Analisa pemanfaatan teknologi informasi dalam pembelajaran jarak jauh di tengah pandemi virus corona covid-19. JISAMAR: Journal of Information System, Applied, Management, Accounting and Research, 4(2), 30-36.

Pratama, M. R. 2015. Hubungan Motivasi Akademik dengan Tingkat Stres Akademik Mahasiswa Keperawatan Semester VI Stikes 'Aisyiyah Yogyakarta (Doctoral dissertation, STIKES'Aisyiyah Yogyakarta).

Rahmadani, C. S. M. 2014. Hubungan antara Sense of Humor dengan Stress Akademik pada Siswa Kelas

Akselerasi SMA Negeri 1 Bireun (Doctoral dissertation, Universitas Medan Area).

Raharjo, D. B., \& Sari, R. R. N. (2020, March 19). Belajar online ditengah corona,ada siswa Mengeluh tensi darah naik. Suara. Retrieved fromhttps://www.suara.com/news/2020/03/19/205940/belajaronline-di-tengah-corona-ada-siswa mengeluh-tensi-darah-naik

Robbins, Stephen P. 2001. Perilaku Organisasi: Konsep, Kontroversi, Aplikasi, Jilid I, Edisi 8, Prenhallindo Jakarta

Sarafino, E.P. 1994. Health Psychology Biopsychosocial Interaction. USA: John Wiley \& Sons . 2006. Health Psychology: Biopsychosocial interactions. Fifth.

Sinaga, M. A. J. 2015. Stres Akademik antara Anak Taman Kanak-kanak yang Mendapat Pengajaran Membaca dan Tidak Mendapat Pengajaran Membaca (Doctoral dissertation, Program Studi Psikologi FPSI-UKSW). 
Siska, M. 2011. Hubungan Efikasi Diri dengan Stres Mahasiswa yang Sedang Mengerjakan Skripsi pada Mahasiswa UIN SUSKA Riau Pekanbaru (Doctoral dissertation, Universitas Islam Negeri Sultan Syarif Kasim Riau).

Shukla, T., Dosaya, D., Nirban, V. S., \& Vavilala, M. P. (2020). Factors extraction of effective teachinglearning in online and conventional classrooms. International Journal of Information and Education Technology, 10(6), 422-427.

Taufik, T., Ifdil, I., \& Ardi, Z. (2013). Kondisi Stres Akademik Siswa SMA Negeri di Kota Padang. JurnalKonseling dan Pendidikan, 1(2), 143-150.

Wardi, R., \& Ifdil, I. (2016). Stress Conditions In Students Completing Thesis. GUIDENA: Jurnal Ilmu Pendidikan, Psikologi, Bimbingan dan Konseling, 6(2), 190-194.

Weinberg RS, Gould D. 2003. Foundations of Sport \& Exercise Psychology. Champaign, IL:Human Kinetics 